\title{
Diagnóstico del Virus de la Celda Real Negra, el Virus de Alas Deformes y el Virus de la Parálisis Aguda en abejas africanizadas (Apis mellifera scutellata), sintomáticas de Costa Rica, utilizando RT-PCR en tiempo real.
}

\author{
Diagnosis of Black Queen Cell Virus, Deformed Wing Virus and Acute Bee Paralysis \\ Virus in symptomatic African honey bees (Apis mellifera scutellata) of Costa Rica using \\ RT-PCR in real time.
}

Guisella Chaves Guevara ${ }^{1}$, Ana Cubero Murillo², Juan Miguel Cordero1, Marina Vicente-Rubiano³, Deborah Kukielka4, Bernal León ${ }^{1}$, José Manuel Sánchez-Vizcaíno³

1 Laboratorio Bioseguridad (LSE), Departamento Diagnóstico Veterinario, Laboratorio Nacional de Servicios Veterinarios, Servicio Nacional de Salud Animal, Ministerio de Agricultura y Ganadería, Heredia Costa Rica. guisella.chaves@senasa.go.cr / juan.cordero@senasa.go.cr / bleon@senasa.go.cr

2 Programa Nacional Apícola, Servicio Nacional de Salud Animal, Ministerio de Agricultura y Ganadería, Heredia Costa Rica. abeja@senasa.go.cr

3 Centro de Vigilancia Sanitaria Veterinaria (VISAVET), Departamento de Sanidad Animal, Universidad Complutense de Madrid,España.marina@sanidadanimal.info / vizacaino@visavet.ucm.es

4 Departamento de Ciencias Farmacéuticas y de la Salud. Área de Microbiología. Facultad de Farmacia. Universidad CEU San Pablo. Madrid, España. deborahkukielka@gmail.com

Recibido: 4 de diciembre de 2015. Corregido: 25 de enero de 2016. Aceptado: 23 de febrero de 2016.

Resumen: Tras denuncias de apicultores, por la presencia de abejas Apis mellifera scutellata enfermas en colmenas localizadas en la región central sur de la provincia de San José, Costa Rica, se recolectó muestras de abejas adultas vivas, con sintomatología presuntiva de infección viral. Las muestras fueron extraídas y procesadas en el laboratorio. A partir de estas muestras, se diagnosticó, por primera vez en Costa Rica, la presencia del virus de la Celda Real Negra (BOCV) y el virus de la Parálisis Aguda (ABPV), en los cantones de: Turrubares, distrito San Pedro; Tarrazú, distrito San Marcos, respectivamente. Además, se confirmó, por PCR, la presencia del virus de las Alas Deformes (DWV) en el país. La información, acerca de las enfermedades virales en Costa Rica, es todavía escasa, por lo cual, la implementación de estas metodologías abre la posibilidad de ofrecer, a los apicultores de este país, un diagnóstico rápido, específico y sensible. La puesta a punto de estas técnicas, además, podría ser el inicio para la realización de investigaciones con el fin de determinar la prevalencia de virus en las colmenas costarricenses, así como posibles factores de riesgo asociados a estas infecciones.

Palabras claves: Abejas Apis mellifera scutellata, RT-PCR tiempo real, SYBR Green, DWV, BOQCV, ABPV, Costa Rica. 


\begin{abstract}
After beekeeper claims of bee diseases in beehives located in the South central region of the province of San José, Costa Rica, samples were collected from live adult Apis mellifera scutellata bees having presumptive symptoms of viral infection. Samples were extracted and processed in the laboratory. This is the first diagnostic in Costa Rica of the presence of the Black Queen Cell Virus (BOCV) and the Acute Bee Paralysis Virus (ABPV) in the province of San José in the canton of Turrubares, the district of San Pedro and the canton of Tarrazú, the district of San Marcos, respectively. Furthermore, this is also the second time that the Deformed Wing Virus DWV was detected in diseased bees in the country, in this occasion using PCR. Information about viral diseases in our country is still scarce; therefore, the implementation of these methods opens the possibility to offer beekeepers a rapid, specific and sensitive diagnosis. The development of these techniques could also be the starting point for conducting research to determine the prevalence of these viruses in beehives as well as potential risk factors associated with these infections.
\end{abstract}

Keywords: Bee Apis mellifera scutellata, RT-PCR real time, SYBR Green, DWV, BOCCV, ABPV, Costa Rica.

\title{
Introducción
}

Las primeras explotaciones apícolas comerciales, en Costa Rica, datan de 1890. A finales de 1984, se dio el ingreso de la abeja africanizada, un híbrido entre la abeja europea (principalmente Apis mellifera lingustica) y la subespecie africana (Apis mellifera scutellata), de mayor agresividad, lo cual provocó que la mayoría de los apicultores abandonara la actividad, sacudiendo la producción nacional, a tal extremo que, en 1987, se pasó de ser un país exportador a importardor de miel. No obstante, en los últimos años, la apicultura ha tenido un crecimiento sostenido, presentándose una mayor cantidad de colmenas en las provincias de: Guanacaste, Puntarenas, Alajuela y San José. Para que esta actividad continúe en apogeo, se requiere de abejas sanas; sin embargo, las abejas melíferas son afectadas por una multitud de parásitos y agentes patógenos, incluyendo: hongos, virus, bacterias y protozoos, todos responsables de gran parte de la pérdida de colmenas (Chen et al. 2004).

Entre las posibles causas, del colapso de colmenas, se ha señalado la infestación de Varroa y la co-infección de agentes virales como causantes en multitud de casos (Allen \& Ball 1996; Ball 1997; Ball \& Bailey 1997; Martin 2001; Sumpter \& Martin 2004).

La relación entre Varroa y los virus es compleja, pues se ha descrito que actúa como vector mecánico y biológico de determinados virus. Se ha determinado que, cuando el ácaro se alimenta de la hemolinfa de las abejas, este puede activar las infecciones encubiertas causadas por virus, tanto en adultos inmaduros como en las etapas de desarrollo (BowenWalker et al. 1999; Martin 2001; Nordström 2003; Chen et al. 2004; Shen et al. 2005; Tentcheva et al. 2006; Gauthier et al. 2007). Cada vez hay más evidencias de que las infecciones virales representan una de las principales amenazas para la salud y el bienestar de estos insectos, por lo cual, son motivo de preocupación en el sector apícola, agrícola y en el ámbito científico (Reddy et al. 2013).

Los virus más comunes, que afectan a las abejas, pertenecen al orden Picornavirales del cual forman parte las familias Iflaviridae y Dicistroviridae (Bailey \& Ball 1991). Los virus, de este orden, son partículas isométricas de $30 \mathrm{~nm}$ de diámetro, que contienen un ARN de cadena 
simple y polaridad positiva. Estos virus causan infecciones inaparentes y persistentes, ya sea de manera individual o en forma simultánea en el hospedero (Dall 1985; Anderson \& Gibbs 1988; Hung et al. 1996).

Dentro de la familia Iflaviridae, se encuentra el género Iflavirus, que incluye las especies del virus de las Alas Deformes (DWV) y Cría Sacciforme (SBV); mientras que la familia Dicistroviridae presenta dos géneros Aparavirus del cual forman parte las especies del virus de la Parálisis Aguda de las Abejas (ABPV), el virus Kashmir (KBV), el virus de la Parálisis Aguda Israelí (IAPV) y Cripavirus que incluye el virus de la Celda Real Negra (BOCV). Por otra parte, el virus de la Parálisis Crónica de las Abejas (CBPV) aún no ha sido clasificado dentro de alguna de las familias conocidas. Bajo condiciones desfavorables y/o de estrés, en la colonia, todos estos virus pueden activar su replicación (infección aparente) y causar una alta mortalidad en las colmenas, si no se controlan de manera adecuada, lo cual podría provocar importantes pérdidas económicas. No obstante, es importante subrayar que los virus de abejas, en general, pueden estar presentes en las colmenas sin que las abejas presenten sintomatologías claras, lo cual es muy común en este tipo de infecciones (Gauthier et al. 2007).

En el 2011, productores de diferentes zonas apícolas de la provincia de San José notificaron pérdida de colonias, reducción en la producción de miel y un aumento en la presencia de enfermedades con síntomas de parálisis, temblor o alas deformes. Estos síntomas hacían suponer una posible infección viral, por lo que estas muestras se procesaron para determinar, en ellas, la presencia de uno o varios de los agentes virales descritos.

El objetivo de esta comunicación consiste en divulgar los resultados sobre la detección, por medio de la técnica de RT-PCR en tiempo real basada en SYBR Green, de los virus Celda Real Negra (BOCV) y el virus de la Parálisis Aguda de las Abejas (ABPV), por primera vez en el país, así como corroborar la presencia del virus de Alas Deformes (DWV) en abejas que presentaron diversos síntomas en colmenas procedentes de tres cantones de la provincia de San José, Costa Rica.

\section{Metodología}

\section{Muestras}

Se tomó tres muestras de abejas Apis mellifera scutellata, pertenecientes a tres apiarios ubicados en la provincia de San José, en los cantones de: Puriscal distrito de Candelarita, Turrubares distrito San Pedro y en Tarrazú distrito de San Marcos, figura 1. Cada muestra consistió en al menos 10 abejas vivas adultas por apiario, localizados en cada uno de estos cantones. Las abejas obtenidas mostraban algún tipo de sintomatología, los cuales se describen en el cuadro 1 . Una vez recolectadas, cada muestra se colocó en un frasco individual y se refrigeraron para su transporte. En el laboratorio, las muestras se mantuvieron a $-20^{\circ} \mathrm{C}$ hasta su procesamiento. 


\section{Homogenización y extracción de ARN}

Por cada 10 abejas se agregó 1,2 mL de PBS 1x estéril pH 7,4, (NaCl: 8 g/L (0,14 M), KCl: 0,20 g/L $(2,7 \mathrm{mM}), \mathrm{KH} 2 \mathrm{PO} 4: 0,20 \mathrm{~g} / \mathrm{L}(1,5 \mathrm{mM}), \mathrm{Na} 2 \mathrm{HPO} 4: 1,15 \mathrm{~g} / \mathrm{L}(8,1 \mathrm{mM})$ y se maceraron en un mortero. Del macerado, se extrajo el ARN utilizando el kit High Pure RNA tissue (Roche Diagnostics Gmbh, Alemania) siguiendo las instrucciones del fabricante. El ARN extraído de cada muestra se eluyó en agua libre de DNasas y RNAasas, y se mantuvo a $-20^{\circ} \mathrm{C}$ hasta su procesamiento.

\section{Retrotranscripción (RT) de las muestras extraídas}

Las muestras se retrotranscribieron utilizando el RevertAid ${ }^{\mathrm{TM}} \mathrm{H}$ Minus kit(Fermentas, E.E.U.U.). Se utilizó $2 \mu \mathrm{L}$ de cada muestra extraída para un volumen de reacción de $20 \mu \mathrm{L}$. La reacción se corrió a $48^{\circ} \mathrm{C}$ durante $30 \mathrm{~min}$ y $95^{\circ} \mathrm{C}$ durante $10 \mathrm{~min}$. Finalizada la retrotranscripción, el ADN complementario (ADNc) se almacenó a $-20^{\circ} \mathrm{C}$.

\section{Controles y determinación de la eficiencia de la PCR y sensibilidad}

Los controles positivos consistieron en muestras positivas y plásmidos, en los cuales se ha clonado el fragmento amplificado por la RT-PCR para siete virus de abejas (ABPV, CBPV, IAPV, KBV, SBV, DWV y BOCV). Para determinar la eficiencia de la PCR, las muestras usadas, como controles, fueron amplificadas y corridas en un gel de agarosa al $2 \%$. Cada una de las bandas positivas se cortó y purificó utilizando OIAquick Gel Extraction Kit de Oiagen. La concentración de cada control purificado se cuantificó en un Nanodrop (Wilmington Delaware, USA). El número de copias por $\mathrm{mL}$ de cada control se determinó utilizando una calculadora molecular (disponible en: http://cels.uri.edu/gsc/cndna.html). Posteriormente, se realizaron diluciones seriadas 1:10 por triplicado de cada control (plásmido o muestra). A partir de esta información se estableció como positiva cualquier muestra con un ciclo umbral $(\mathrm{Ct})$ inferior al límite de detección de la PCR. Las muestras con un Ct igual o superiores al límite de detección se consideraron sospechosas; se evaluaron sus Tm respectivas y se corrieron, en un gel de agarosa, para determinar la presencia de la banda esperada. Finalmente, cada plásmido o muestra control se diluyó y ajustó su concentración para obtener controles positivos con un $\mathrm{Ct}$ de $25 \pm 1$. Estos controles se usaron, durante el proceso de la PCR junto con un control negativo de reactivos, con el fin de determinar la validez de la PCR. En todos los casos se determinó la temperatura de fusión (Tm) para asegurar la especificidad del diagnóstico de cada uno de los virus.

\section{Prueba PCR tiempo real, utilizando SYBR Green, para la detección individual de siete virus que infectan abejas.}

Cada PCR utilizada, en este análisis, ha sido publicada previamente, ABPV y SBV (Kukielka \& Sánchez-Vizcaíno 2009) based on SYBR Green (SG, BOCV y DWV (Kukielka et al. 2008) IAPV (Palacios et al. 2008), KBV (Soltz et al. 1995) y CBPV (Ribière et al. 2002). Las condiciones de temperatura y tiempo de cada programa, en cada uno de los siete PCRs, fueron adaptadas 
de acuerdo con los reactivos utilizados. Todas las reacciones se realizaron con SYBR Green/ ROX qPCR, Master mix $2 X$, Fermentas e incluyeron, además de los controles descritos, un control positivo débil (determinado durante la prueba para establecer el límite de detección). La concentración equimolar final de los "primers" o iniciadores para los siete virus analizados en este estudio fue: ABPV 0,3 $\mu \mathrm{M}, \mathrm{BOCV} 0,3 \mu \mathrm{M}, \mathrm{CBPV} 0,4 \mu \mathrm{M}$, DWV 0,4 $\mu \mathrm{M}$, IAPV $0,3 \mu \mathrm{M}, \mathrm{KBV} 0,4 \mu \mathrm{M}$, y SBV 0,2 $\mu \mathrm{M}$. En la reacción se empleó $2 \mu \mathrm{L}$ del ADNc para cada virus. Se ajustó el volumen final a $12,5 \mu \mathrm{L}$ con agua libre de ADNasas y ARNasas. Se utilizó un termociclador de tiempo real 7500 (Applied Biosystem, USA).

Los límites de detección establecidos para cada virus, de acuerdo con su Ct fueron: ABPV 34,8, BOCV 36,9, CBPV 30,2, DWV 30,8, IAPV 33,9, KBV 36,0, SBV 35,5. Por otra parte; las PCR que mostraron una mejor sensibilidad fueron SBV 16,4 copias/ $\mu \mathrm{L}, \mathrm{CBPV} 18,3$ copias $/ \mu \mathrm{L}$ y BOCV 19,9 copias/ $\mu \mathrm{L}$; mientras que las PCR menos sensibles fueron DWV con 169 copias/ $\mu \mathrm{L}$ e IAPV con 100 copias/ $\mu \mathrm{L}$.

\section{Secuenciación de los productos de PCR amplificados.}

Las muestras amplificadas, correspondientes a los virus analizados, fueron secuenciadas. Para ello, cada muestra positiva fue corrida en geles de agarosa al $2 \%$ para ser purificados con el kit OlAquick Gel Extraction (Qiagen). La reacción de secuenciación se llevó a cabo con el kit BigDye Terminator v3.1. Cycle Sequencing (Life Technologies). Las reacciones se procesaron en un analizador genético ABI 3130 (Life Technologies). Los resultados fueron alineados y analizados con el Software SeqScape v2.7; posteriormente, se compararon con la base de datos Genbank/ DDBJ / EMBL.

\section{Análisis filogenético de los virus en las muestras de abejas con sintomatología.}

Para la realización del análisis filogenético se descargaron secuencias del Genbank/ DDB] / EMBL, correspondientes a los virus positivos. En este caso, las secuencias correspondientes a los genes de la poliproteína estructural para BOCV, de la región 5' no codificante para DWV y de la polimerasa RNA dependiente de ARN para ABPV. Las secuencias, identificadas en este estudio, se alinearon y editaron utilizando el programa Bioedit (Hall 1999). El alineamiento se corroboró usando el programa Guidance (Penn et al. 2010). Finalmente, se eliminó las secuencias que mostraban un $100 \%$ de identidad en el algoritmo de distancia por parejas del programa MEGA 6 (Tamura et al. 2013). Se utilizó el mejor modelo de sustitución, en concordancia con el Criterio de Información Akaike y Bayesiano (AIC y BIC). Finalmente, se construyeron los árboles filogenéticos utilizando el método de distancia de Máxima verisimilitud programa MEGA 6, con un bootstrap de 1000 repeticiones. Las secuencias de los virus ABPV y BOCV pueden ser accesadas en el genbank con los códigos KU563736 y KU563737 respectivamente, el fragmento amplificado de DWV es menor a 200 pb por lo cual no cumple con los requisitos de aceptación establecidos por el National Center for Biotechnology Information NCBI. 


\section{Resultados y discusión}

Tal y como se menciona en la introducción, son varios los agentes etiológicos que pueden causar enfermedades en las abejas. No obstante; no todos producen los síntomas observados en los apiarios de los cuales se recolectaron las muestras enviadas al Laboratorio. Por ejemplo, las enfermedades bacterianas, tales como Loque europeo y Loque americano, se manifiestan en la cría de las abejas, por lo cual se descartaron como diagnóstico diferencial (Alippi 1992).

Por su parte, Nosema apis produce, en infestaciones altas, diarrea; la cual se hace evidente a través de la presencia de manchas fecales en las estructuras de la colmena (Higes et al. 2010). Esta sintomatología no se observó durante la toma de las muestras.

Varroa destructor no presenta sintomatología evidente cuando las infestaciones son leves. En el caso de infestaciones fuertes, los ácaros producen lesiones que obligan, a las abejas, a arrastrarse, debido a alteraciones en la capacidad para volar, con una consecuente reducción en la tasa de retorno a la colonia después del forrajeo, se disminuye la vida útil y el peso de las obreras (Shimanuki et al. 1994), en ninguno de los casos se observó una infestación alta de varroa, por lo cual no se determinó el porcentaje de infestación.

Los síntomas descritos por los apicultores de los apiarios muestreados son característicos de las infecciones causadas por virus.

En el cuadro 1 y figura 1, se presentaron datos relacionados con la localización y características de las muestras recolectadas. Estas muestras se analizaron para cada uno de los siete virus estudiados, solo tres de estos virus presentaron amplificación, según el criterio de validación establecido.

La muestra de Turrubares fue positiva a BOCV, mientras que, la recolectada en San Marcos de Tarrazú, fue positiva a ABPV. Por su parte, DWV fue detectado en la muestra proveniente del cantón de Puriscal y mostró la mayor carga viral $(\mathrm{Ct}=13,51)$ en comparación con las otras dos muestras analizadas, cuyos Ct estuvieron cercanos al límite de detección de las pruebas (cuadro 2).

El DWV es, actualmente, uno de los principales virus asociados con el colapso de las colonias de abejas en presencia de Varroa destructor (Ball \& Allen 1988; Bowen-Walker et al. 1999; Nordström et al. 1999; Sumpter \& Martin 2004; Tentcheva et al. 2006). DWV se encuentra, además, ampliamente difundido en los apiarios, detectado con mucha frecuencia en altas prevalencias (Tentcheva et al. 2004; Berényi et al. 2007). La sintomatología observada en las abejas recolectas en el apiario, ubicado en el cantón de Puriscal, es característica del virus DWV y fue congruente con el virus identificado. DWV provoca una reducción en el tamaño del cuerpo y de las alas (las cuales se observan arrugadas y de menor tamaño), así como la decoloración en las abejas adultas (Cordoni 2011). La infección de DWV se detecta en la fase inmadura (huevos, larvas y pupas); también en la fase adulta de la abeja (Bailey \& Ball 1991; Ball \& Bailey 1997; Chen \& Siede 2007). En este caso, la sintomatología observada en las abejas analizadas en el estudio, es muy típica a la producida por este virus, el cual no 
Cuadro 1. Distribución de las muestras recogidas ante la denuncia de los apicultores por cantón/ distrito, época del año en que se recolectó la muestra y sintomatología observada en las abejas.

\begin{tabular}{ccccc}
\hline Cantón/ & Coordenadas & $\begin{array}{c}\text { Mes y estación } \\
\text { del año en que } \\
\text { se recolectó la } \\
\text { muestra }\end{array}$ & Sintomatología & Virus detectado \\
\hline $\begin{array}{c}\text { Tarrazú/San } \\
\text { Marcos }\end{array}$ & $\begin{array}{c}-84.021267 \\
9.655260\end{array}$ & $\begin{array}{c}\text { Marzo-11 Época } \\
\text { seca }\end{array}$ & $\begin{array}{c}\text { Abejas con parálisis, } \\
\text { temblores y sin } \\
\text { poder volar }\end{array}$ & ABPV \\
$\begin{array}{c}\text { Puriscal/ } \\
\text { Candelaria }\end{array}$ & -84.333302 & Agosto-11 & $\begin{array}{c}\text { Abejas frente a la } \\
\text { piquera mostrando } \\
\text { alas deformadas con } \\
\text { Imposibilidad para } \\
\text { volar }\end{array}$ & DWV \\
$\begin{array}{c}\text { Turrubares/San } \\
\text { Marcos }\end{array}$ & 84.8 & Época lluviosa & $\begin{array}{c}\text { Abejas sin pelo que } \\
\text { se encontraban } \\
\text { fuera de la piquera }\end{array}$ & BOCV \\
\hline
\end{tabular}

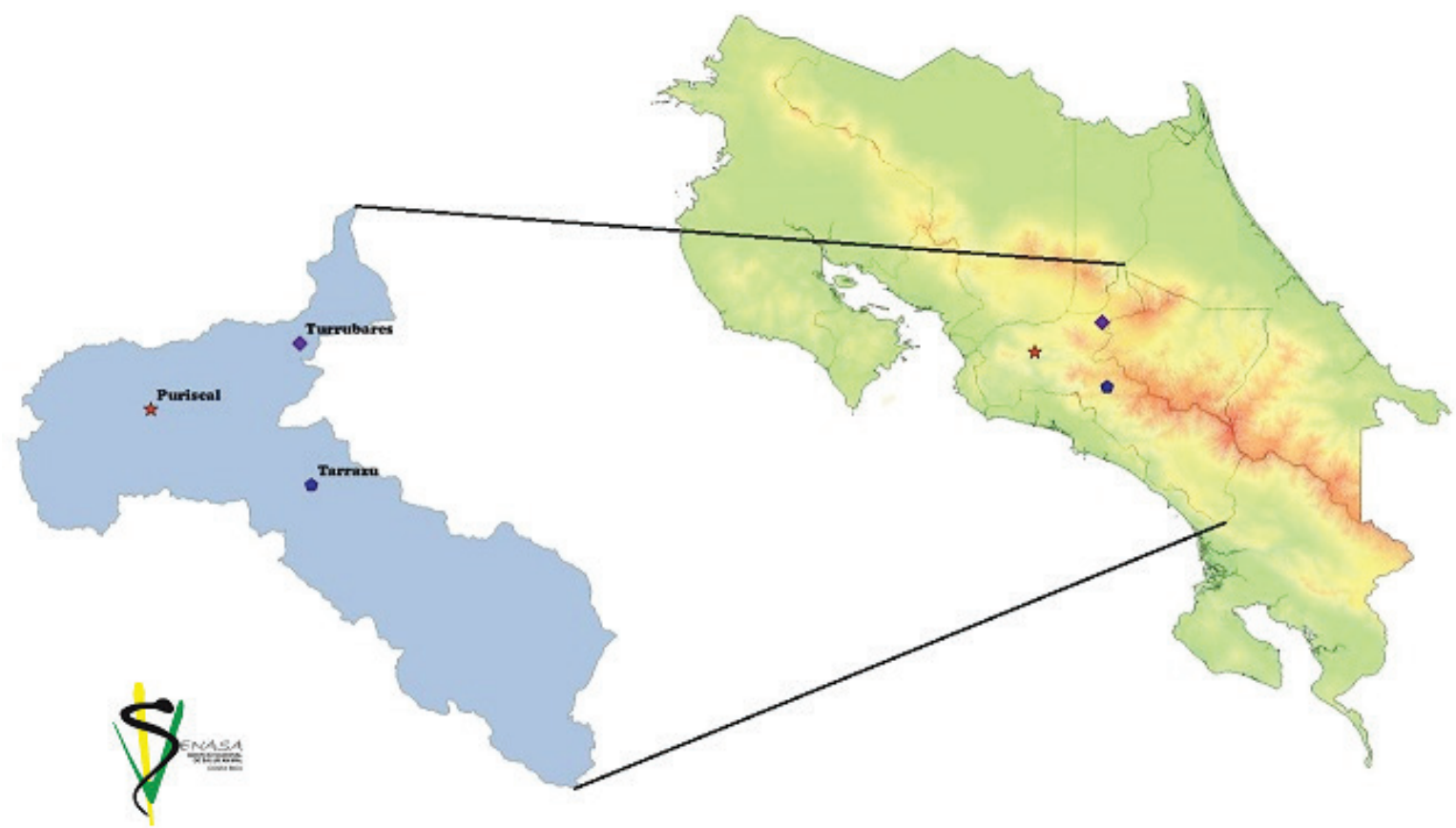

Figura 1. Este mapa muestra el relieve y la distribución territorial, por provincias, de Costa Rica. Se resalta, en azul, la provincia de San José, así como la ubicación de las localizaciones donde se detectaron los virus DWV (estrella), BOCV (rombo) y ABPV (pentano). 
Cuadro 2. Ct, Tm, modelo de sustitución seleccionado por AIC o BIC, número de secuencias analizadas así como grupo externo utilizado para enraizar el árbol.

\begin{tabular}{cccccc}
\hline Virus & CT & Tm & $\begin{array}{c}\text { Modelo de sustitución AIC/ } \\
\text { BIC }\end{array}$ & $\begin{array}{c}\text { Número de } \\
\text { secuencias de } \\
\text { referencia }\end{array}$ & Grupo externo \\
\hline ABPV & 33,25 & 77 & T92+I & 17 & $\begin{array}{c}\text { Virus de la parálisis } \\
\text { aguda Israelí }\end{array}$ \\
BOCV & 32,93 & 79 & T92+G & 16 & Ninguno \\
DWV & 13,51 & 79 & K80 & 14 & $\begin{array}{c}\text { Ectropis obliqua } \\
\text { virus }\end{array}$ \\
\hline
\end{tabular}

solo afecta a abejas melliferas sino también a otras especies como abejorros (bumble bees), en los cuales manifiesta la misma sintomatología, aún en ausencia de varroa destructor, lo que refuerza el papel de este virus como agente causal en abejorros de esta sintomatología. Este hallazgo, también fue descrito en un estudio realizado en Apis mellifera, en el que se asoció la presencia de DWV con pérdida de colonias aún en ausencia de Varroa destructor (Genersch et al. 2010). En Costa Rica, este virus, así como KBV fueron descritos, por primera vez, en abejas africanizadas en la zona de los Santos; también, en la provincia de San José, en septiembre del 2002 (Calderón et al. 2003). En esa ocasión, se observó los mismos síntomas que presentaron las abejas en Puriscal; pero, en el 2002, se describió, además, una alta mortalidad, con un nivel de infestación del ácaro Varroa destructor en las colmenas superior al 10\%, (Calderón et al. 2003).

En el caso de BOCV, este virus se encuentra en abejas adultas, larvas y pupas, pero la sintomatología se observa sólo en la pupa de la abeja reina. Las crías de zángano u obrera y las obreras adultas pueden ser infectadas por el virus, sin que presenten alteraciones morfológicas (Siede \& Büchler n.d.; Bailey \& Woods 1977). Las abejas obreras transmiten el virus a las larvas con las secreciones de comida en la cría (Allen \& Ball 1996). Las colmenas, de las cuales se obtuvo la muestra de Turrubares, no mostraron ninguna sintomatología compatible con la presencia de BOCV, aparte de lo descrito en el cuadro 1, lo cual podría estar ligado a la leve carga viral de BOCV observada en la muestra analizada en comparación con DWV (cuadro 2). No obstante, ningún otro virus, de los seis restantes estudiados, pudo ser amplificado en esa muestra. Se ha indicado, en la literatura, que este virus se encuentra en estrecha relación con el microsporidio Nosema apis, un hongo intracelular de las abejas melíferas, que acorta la vida de las abejas infestadas (Allen \& Ball 1996).

Son necesarios futuros estudios para saber qué papel puede estar desarrollando BOCV en las colmenas de Costa Rica. Especial atención debe prestarse para evaluar el impacto de la carga de Nosema sp sobre BOCV y el efecto de este virus y su carga viral en la colmena. 
En el caso de ABPV, se ha descrito que desempeña un papel importante en el colapso de las colonias de abejas infestadas con Varroa destructor, parásito que también transmite este virus (Ball \& Allen 1988; Faucon et al. 1992; Békési et al. 1999). ABPV produce mortalidad en abejas adultas, en las cuales se observa síntomas tales como abdomen distendido y parálisis, por lo cual, las abejas tienden a arrastrarse, (Békési et al. 1999), mientras que en las crías, se detecta un colapso repentino, con retardo en la ganancia de peso y un cambio remarcado en la apariencia (Azzami et al. 2012). También, se ha señalado que este virus puede estar presente en abejas sin que se observe síntomas aparentes (Bakonyi et al. 2002). En las muestras, obtenidas en Costa Rica, no se observó una reducción importante en la población de la colmena al momento de realizar el muestreo. Sin embargo, en el caso particular de la colmena positiva a ABPV, las abejas mostraban síntomas compatibles con los causados por este virus, aunque la carga viral fue baja. Según (Highfield et al. 2009), este virus es capaz de producir infecciones de tipo aguda clásica a pesar de presentar cargas virales relativamente bajas ( $10^{3}$ a $10^{6}$ virus por abeja) lo cual podría explicar el por qué se detectó este virus en las abejas que mostraron parálisis con niveles bajos de infección, los cuales fueron evidenciados en los altos Ct observados en el PCR tiempo real.

Por otra parte, otros virus, tales como el virus de la Parálisis Crónica de las abejas (CBPV) o el virus de la Parálisis Aguda Israelí (IAPV), que pueden producir parálisis, como la observada en las abejas remitidas al laboratorio de Bioseguridad del Laboratorio Nacional de Servicios Veterinarios LSE-LANASEVE, no fueron detectados en las muestras analizadas, por lo cual, se corrobora el hallazgo de la presencia de ABPV en abejas, al presentar sintomatología compatible con este virus.

En un estudio realizado, con el fin de establecer la causa del despoblamiento de las abejas Apis mellifera en Guatemala, entre el 2005 y 2006, observaron que, de cuatro virus estudiados, $A B P V, B O C V$ y DWV, se encontraron infectando persistentemente todos los apiarios evaluados, mientras que la presencia de KBV no fue evidenciada durante la ejecución del estudio. De acuerdo con los hallazgos descritos en esa publicación, la incidencia de los virus muestreados aumentó inmediatamente, después de que se presentara una disminución en la población de abejas (Landaverde et al. 2012). Según estos autores, DWV y BOCVV podrían estar comportándose más bien como agentes oportunistas, tras el debilitamiento y la pérdida de las colonias, que como la causa del colapso de las colmenas per se (Landaverde et al. 2012). Así mismo, se ha descrito la presencia de varios virus infectando Apis mellifera en otros países de la región, como Belice, donde se detectó ABPV, BOCV, SBV y el virus $Y$ de las abejas (BYV); Honduras, donde se notificó el virus SBV y Nicaragua, casos positivos a ABPV y SBV (Allen \& Ball 1996). Sin embargo, en ninguno de estos hallazgos se menciona la asociación de estos virus con estados patogénicos observables en las abejas, con excepción del estudio realizado en Guatemala. En términos generales, la información concerniente a la presencia de estos virus en Centroamérica, a diferencia de Europa, es bastante escasa y, más aún, en abejas de la especie Apis mellifera scutellata.

Las muestras amplificadas, en este estudio, fueron secuenciadas; $y$ los análisis filogenéticos, de estas muestras, se presentan en las figuras 2-4. En la figura 2, DWV se ubica en un "cluster" junto con el control positivo, ambos agrupados dentro de un nodo que comparte 


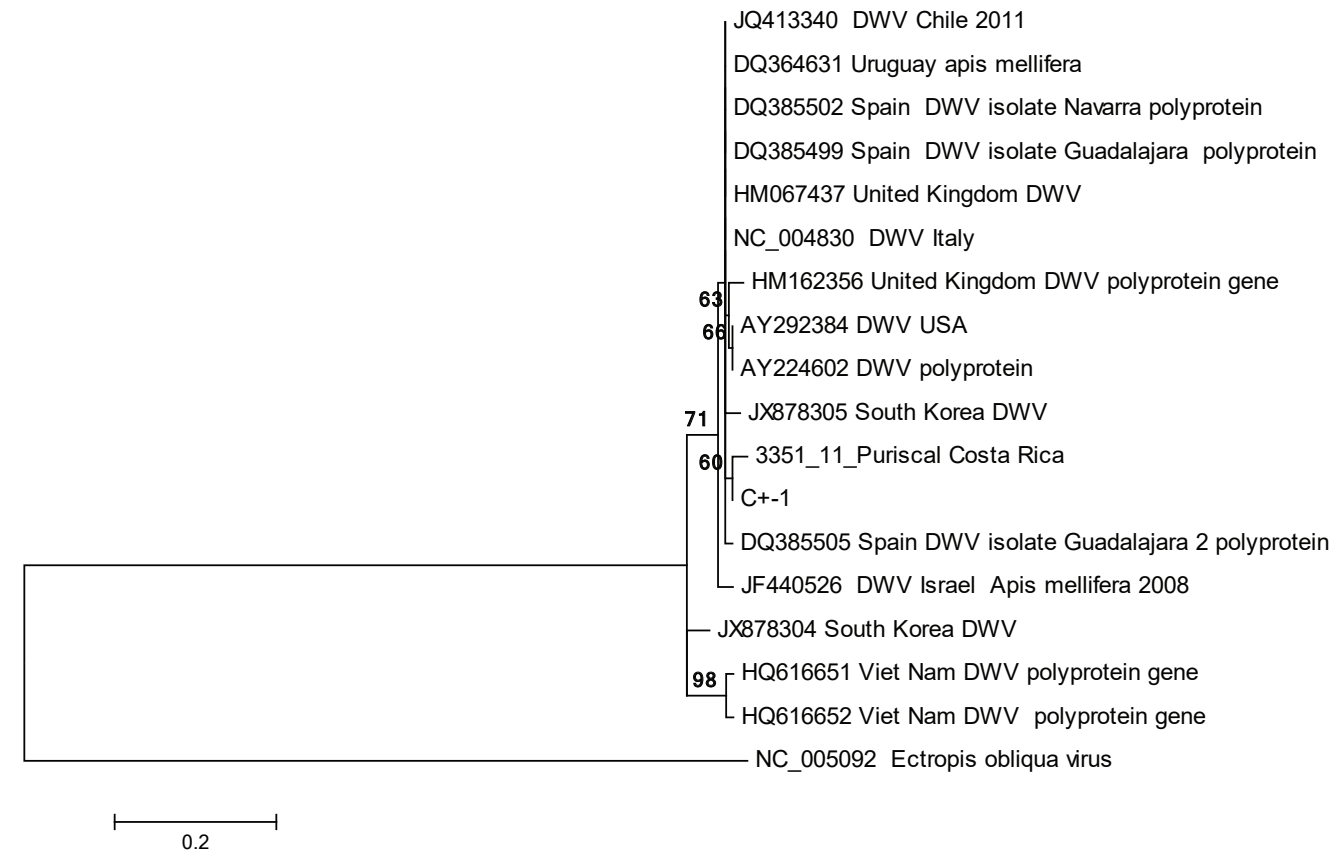

Figura 2. Árbol filogenético del virus de las Alas Deformes (DWV). El árbol fue construido con el método de Máxima Verisimilitud, usando K80 como modelo de sustitución con un boostrap de 1000 repeticiones. El virus de Ectopis obliqua se usó como grupo externo.

un ancestro común con variantes de Europa y Sudamérica y una de Korea. En otros "cluster" se agrupan secuencias de Korea, Israel, Vietnam y una de España.

En el caso de BOCV, la muestra de Costa Rica se agrupa con variantes de Asia, Europa y Estados Unidos. Dos muestras de Sudamérica, una de Uruguay y otra de Perú, están externas al grupo de Costa Rica (figura 3). En este árbol no se incluyó una secuencia de referencia externa, debido a que las diferencias, en cantidad de nucleótidos observadas entre las secuencias de BOCV analizadas, fue muy reducida, en comparación con las diferencias presentes en la secuencia del grupo externo, lo cual provoca que todas las secuencias de BOCV evaluadas quedaran al mismo nivel.

Por su parte, la secuencia de ABPV se observa en un "cluster" separado de las variantes Europeas, indicando que es una secuencia con un linaje diferente. Externo a este "cluster", se ubica una secuencia de ABPV, aislada de guano de murciélagos insectívoros, aislados en E.E.U.U. La secuencia de IAPV, usada como grupo externo, podría indicar que la secuencia obtenida del virus aislada de guano de murciélagos insectívoros fue mal clasificada, o que, en el fragmento evaluado en esta secuencia presenta una semejanza al virus IAPV.

Aunque la información contenida, en los árboles filogenéticos, puede orientar el origen de estos tres virus en abejas africanizadas de Costa Rica, es necesario interpretar estos árboles 


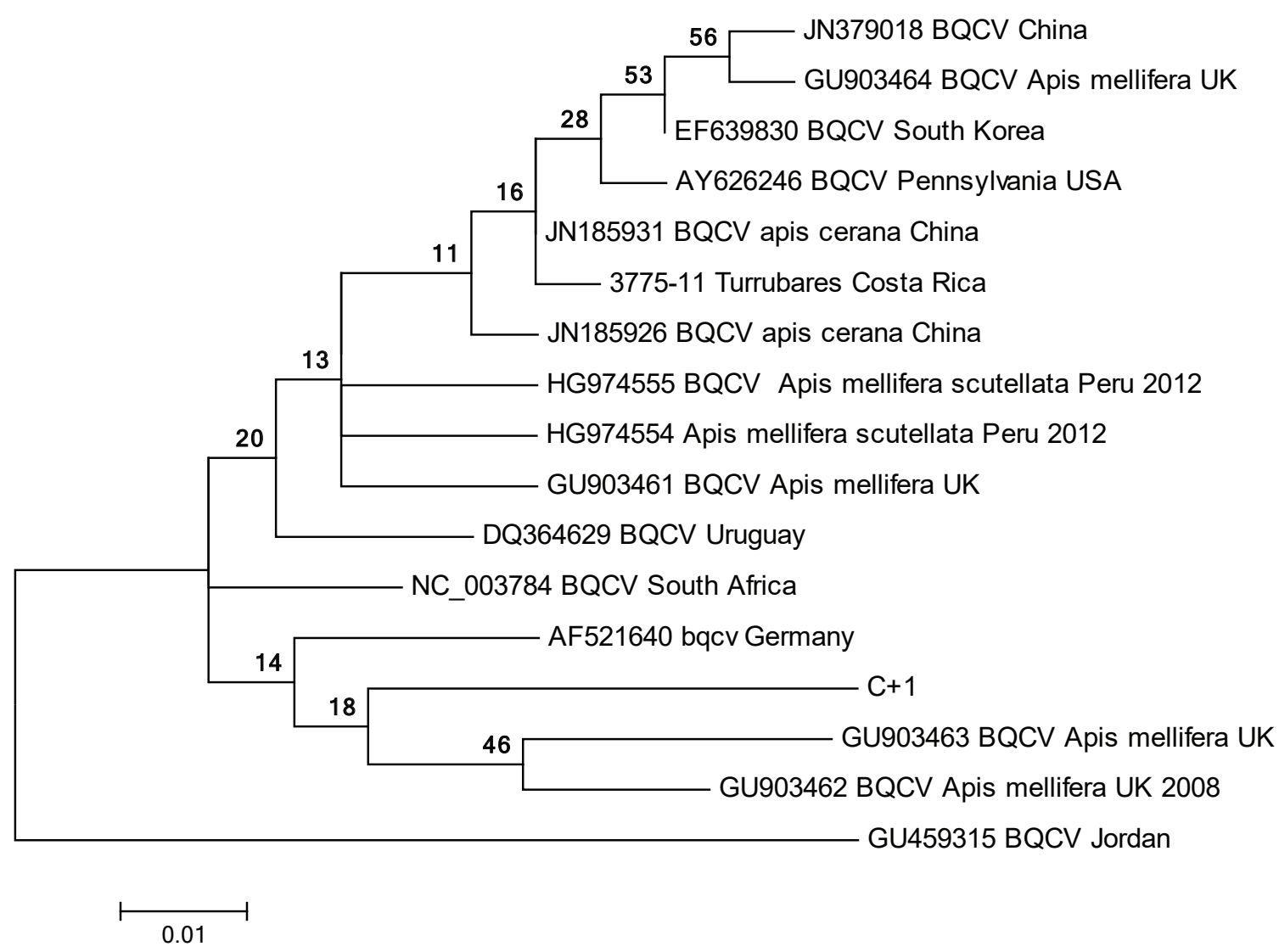

Figura 3. Árbol filogenético sin raíz del virus de la Celda Negra Real (BOCV). Árbol construido con el método de inferencia de Máxima Verisimilitud, usando T92+G como modelo de sustitución con un boostrap de 1000 repeticiones. No se incluye secuencia externa (outgroup) debido a la poca variabilidad de las muestras en la región amplificada.

con precaución, por tres motivos. En primer lugar, el reducido tamaño de los fragmentos amplificados (DWV 158 pb, BOCV 222 pb y ABPV 298 pb). En segundo lugar, los fragmentos de los genes que codifican, para la región 5', no codificante de DWV, y el gen de la proteína de la capside (BOCV) podrían no ser lo suficientemente informativos. Finalmente, existe poca cantidad de secuencias registradas en el Genbank/DDBJ/ EMBL para estas regiones y estos virus, reduciendo la riqueza de información que podría obtenerse de los árboles, al compararlas con nuestras secuencias.

En este estudio se ha detectado, por primera vez, la presencia de los virus BOCV y ABPV infectando abejas Apis mellifera scutellata con sintomatología, en Costa Rica, en dos cantones diferentes de la provincia de San José y confirma la presencia de DWV por PCR en apiarios del cantón de Puriscal, de la misma provincia. Adicionalmente, se ha implementado 


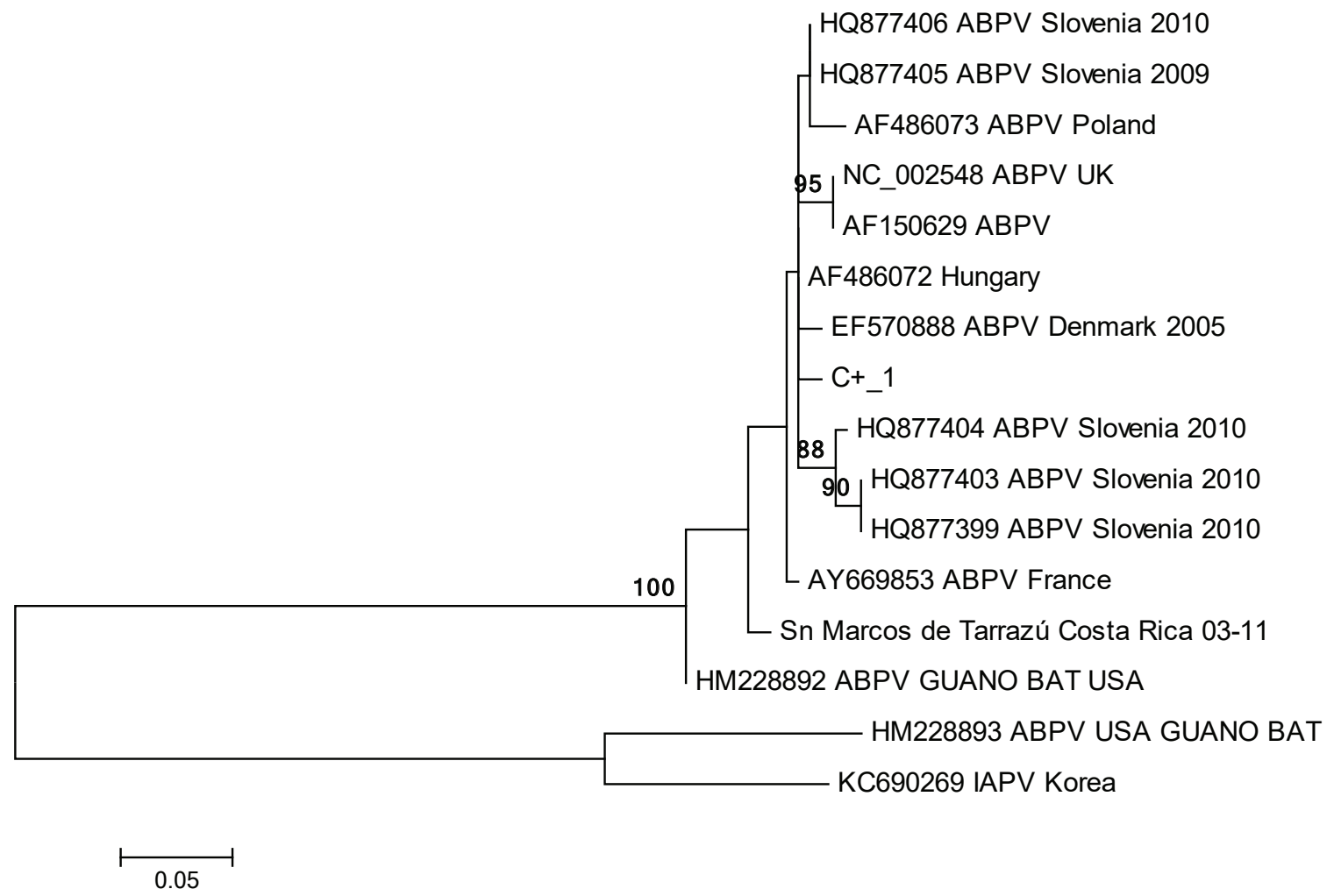

Figura 4. Árbol filogenético del virus de la parálisis aguda (ABPV). El árbol fue construido con el método de inferencia de Máxima Verisimilitud, usando T92+I como modelo de sustitución con un boostrap de 1000 repeticiones., se usó una secuencia del virus de la parálisis aguda Israelita como grupo externo.

varios métodos de PCR tiempo real, para la detección de otros cuatro virus que afectan a las abejas, ofreciendo al productor un diagnóstico rápido, práctico y seguro que permite, además, la posibilidad de caracterizar molecularmente los virus detectados.

\section{Agradecimientos}

Los autores quieren agradecer al personal del SENASA, quienes recolectaron las muestras utilizadas en este estudio. Este trabajo forma parte del proyecto "Estandarización y validación de pruebas de PCR para el diagnóstico y posterior estudio epidemiológico de enfermedades virales en abejas africanizadas (Apis mellifera) de Costa Rica", financiado por la Universidad Complutense de Madrid, España (VIII Convocatoria de Cooperación al desarrollo UCM). Marina Vicente-Rubiano está financiada por el programa de becas de Formación del Profesorado Universitario (FPU-2010) del Ministerio de Educación y Cultura de España. 
Rev. Ciencias Veterinarias, Vol. 34, N 1, [7-21], ISSN: 2215-4507, enero-junio, 2016

DOI: http://dx.doi.org/10.15359/rcv.34-1.1

URL: http://www.revistas.una.ac.cr/index.php/veterinaria/index

\section{Referencias}

Alippi, A.M. 1992. Detección de Bacillus larvae en poblaciones mixtas de esporas bacterianas a partir de restos larvales. Microbiología 8: 115-118

Allen, M. \& Ball, B. 1996. The incidence and world distribution of honey bee. Bee World 77: 141-162. DOI: http://dx.doi.org/10.1080/0005772X.1996.11099306.

Anderson, D.L. \& Gibbs, A.J. 1988. Inapparent Virus Infections and their Interactions in Pupae of the Honey Bee (Apis mellifera Linnaeus) in Australia. J. Gen. Virol. 69: 1617-1625. DOI:http://dx.doi.org/10.1080/0005772X.1996.11099306.

Azzami, K., Ritter, W., Tautz, J. \& Beier, H. 2012. Infection of honey bees with acute bee paralysis virus does not trigger humoral or cellular immune responses. Arch. Virol.157: 689-702. DOI: http://dx.doi.org/10.1007/s00705-012-1223-0.

Bailey, L. \& Ball, B. 1991. Honey bee pathology. Academic Press., London.

Bailey, L. \& Woods, R. 1977. Two More Small R N A Viruses from Honey Bees and Further Observations on Sacbrood and Acute Bee-Paralysis Viruses. J. Gen. ViroL 37: 175-182. DOI: http://dx.doi.org/10.1099/0022-1317-37-1-175.

Bakonyi, T., Grabensteiner, E., Kolodziejek, J., Rusvai, M., Topolska, G., Ritter, W. \& Nowotny, N. 2002. Phylogenetic Analysis of Acute Bee Paralysis Virus Strains Phylogenetic Analysis of Acute Bee Paralysis Virus Strains. Appl. Environ. Microbiol. 68(12): 6446-50. DOI: http://dx.doi.org/10.1128/AEM.68.12.6446-6450.2002.

Ball, B. V \& Bailey, B. 1997. No Title, p. 13-31. In R. Morse, K. Flottum \& A.I. Root (eds.). Honey Bee Pests, Predators and Diseases. Ohio, USA.

Ball, B. V. \& Allen, M.F. 1988. The prevalence of pathogens in honey bee (Apis mellifera) colonies infested with the parasitic mite Varroa jacobsoni. Ann. Appl. Biol. 113: 237244. DOI: http://dx.doi.org/10.1111/j.1744-7348.1988.tb03300.x.

Ball, B.1997. Varroa and viruses, p. 11-15. In Varroa Fight the Mite. International Bee Research Association, Cardiff.

Békési, L., Ball, B. V, Dobos-Kovács, M., Bakonyi, T. \& Rusvai, M. 1999. Occurrence of acute paralysis virus of the honey bee (Apis mellifera) in a Hungarian apiary infested with the parasitic mite Varroa jacobsoni. Acta Vet. Hung. 47: 319-24. DOI: http://dx.doi. org/10.1556/AVet.47.1999.3.5.

Bowen-Walker, P., Martin, S. \& Gunn, A. 1999. The transmission of deformed wing virus between honeybees (Apis mellifera L.) by the ectoparasitic mite varroa jacobsoni Oud. J. Invertebr. Pathol. 73: 101-6. DOI: http://dx.doi.org/10.1006/jipa.1998.4807.

Calderón, R., Van Veen, J., Arce, H.G. \& Esquivel, M.E. 2003. Presence of deformed wing virus and Kashmir bee virus in Africanized honey bee colonies in Costa Rica infested with Varroa destructor. Bee world 84: 112-116. DOI: http://dx.doi.org/10.1080/00057 72X.2003.11099586. 
Chen, Y., Zhao, Y., Hammond, J., Hsu, H., Evans, J. \& Feldlaufer, M. 2004. Multiple virus infections in the honey bee and genome divergence of honey bee viruses. J. Invertebr. Pathol. 87: 84-93. DOl: http://dx.doi.org/10.1016/j.jip.2004.07.005.

Chen, Y.P. \& Siede, R. 2007. Honey bee viruses. Adv. Virus Res. 70: 33-80. DOI: http://dx.doi. org/10.1016/S0065-3527(07)70002-7.

Cordoni, G. 2011. Epidemiology and Taxonomy of Honey Bee Viruses in England and Wales. University of Surrey.

Dall, D. 1985. Inapparent infection of honey bee pupae by Kashmir and sacbrood bee viruses in Australia. Ann. Appl. Biol. 106: 461-468. DOI: http://dx.doi. org/10.1111/j.1744-7348.1985.tb03136.x

Faucon, J.P., Vitu, C., Russo, P. \& Vignoni, M. 1992. Diagnostic de la paralysie aiguë application à l'épidémiologie des maladies virales de l'abeille en France en 1990. Apidologie 23: 139-146. DOI: http://dx.doi.org/10.1051/apido:19920206

Gauthier, L., Tentcheva, D., Tournaire, M., Laurent, G., Diana, T., Magali, T., Benjamin, D., François, C., C, M.E. \& Max, B. 2007. Viral load estimation in asymptomatic honey bee colonies using the quantitative RT-PCR technique. Apidologie 38: 426-435. DOI: http://dx.doi.org/10.1051/apido:2007026.

Genersch, E., Von Der Ohe, W., Kaatz, H., Schroeder, A., Otten, C., Büchler, R., Berg, S., Ritter, W., Muhlen, W., Gisder, S., Meixner, M., Liebig, G., Rosenkranz, P., 2010. The German bee monitoring project:a long term study to understand periodically high winter losses of honey bee colonies. Apidologie 41, 332-352. DOI: http://dx.doi.org/10.1051/apido/2010014.

Hall, T.A. 1999. BioEdit: a user-friendly biological sequence alignment editor and analysis program for Windows 95/98/NT. Nucl. Acids. Symp. 41: 95-98.

Higes, M., Martín-Hernández, R. \& Meana, A. 2010. Nosema ceranae in Europe: an emergent type C nosemosis. Apidologie 41: 375-392. DOI http://dx.doi.org/10.1051/apido/2010019.

Hung, A.C.F., Shimanuki, H. \& Knox, D.A. 1996. Inapparent infection of acute bee paralysis virus and Kashmir bee virus in the U.S. honey bees. Am. Bee J. 1: 874-876.

Kukielka, D., Esperón, F., Higes, M. \& Sánchez-Vizcaíno, J.M. 2008. A sensitive one-step realtime RT-PCR method for detection of deformed wing virus and black queen cell virus in honeybee Apis mellifera. J. Virol. Methods 147: 275-81. DOI: http://dx.doi. org/10.1016/j.jviromet.2007.09.008.

Kukielka, D. \& Sánchez-Vizcaíno, J.M. 2009. One-step real-time quantitative PCR assays for the detection and field study of Sacbrood honeybee and Acute bee paralysis viruses. J. Virol. Methods 161: 240-6. DOI: http://dx.doi.org/10.1016/j.jviromet.2009.06.014.

Martin, S. 2001. The role of Varroa and viral pathogens in the collapse of honeybee colonies: a modelling approach. J. Appl. Ecol. 53 105-112. DOI: http://dx.doi.org/10.1046/ j.1365-2664.2001.00662.x. 
Nordström, S. 2003. Distribution of deformed wing virus within honey bee (Apis mellifera) brood cells infested with the ectoparasitic mite Varroa destructor. Exp. Appl. Acarol. 29: 293-302. DOI http://dx.doi.org/10.1023/A:1025853731214.

Nordström, S., Fries, I., Aarhus, A., Henrik, H. \& Korpela, S. 1999. Virus infections in Nordic honey bee colonies with no, low or severe Varroa jacobsoni infestations. Apidologie 30: 475-484. DOI: http://dx.doi.org/10.1051/apido:19990602.

Palacios, G., Hui, J., Quan, P.L., Kalkstein, a, Honkavuori, K.S., Bussetti, a V, Conlan, S., Evans, J., Chen, Y.P., vanEngelsdorp, D., Efrat, H., Pettis, J., Cox-Foster, D., Holmes, E.C., Briese, T. \& Lipkin, W.I. 2008. Genetic analysis of Israel acute paralysis virus: distinct clusters are circulating in the United States. J. Virol. 82: 6209-17. DOl:http://dx.doi.org/10.1128/JVI.00251-08.

Penn, O., Privman, E., Ashkenazy, H., Landan, G., Graur, D. \& Pupko, T. 2010. GUIDANCE: a web server for assessing alignment confidence scores. Nucleic Acids Res. 38: W23-8. DOI: http://dx.doi.org/10.1093/nar/gkq443.

Ribière, M., Triboulot, C., Mathieu, L., Aurières, C., Faucon, J.-P. \& Pépin, M. 2002. Molecular diagnosis of chronic bee paralysis virus infection. Apidologie 33: 339-351. DOI: http:// dx.doi.org/10.1051/apido:2002020.

Shen, M., Yang, X., Cox-Foster, D. \& Cui, L. 2005. The role of varroa mites in infections of Kashmir bee virus (KBV) and deformed wing virus (DWV) in honey bees. Virology 342: 141-149. DOI: http://dx.doi.org/10.1016/j.virol.2005.07.012.

Siede, R. \& Büchler, R. n.d. 2003. Symptomatic Black Queen Cell Virus infection of drone brood in Hessian apiaries. Berl. Munch. Tierarztl. Wochenschr. 116: 130-133.

Soltz, D., Shen, X.-R., Boggis, C. \& Sisson, G. 1995. Molecular diagnosis of Kashmir bee virus Infection. J. Apic. Res. 34: 153-160. DOI: http://dx.doi.org/10.1080/00218839.1995.1 1100900.

Sumpter, D. \& Martin, S. 2004. The dynamics of virus epidemics in varroa-infested honey bee colonies. J. Anim. Ecol 73: 51-63. DOI: http://dx.doi.org/10.1111/j.13652656.2004.00776.x.

Tamura, K., Stecher, G., Peterson, D., Filipski, A. \& Kumar, S. 2013. MEGA6: Molecular Evolutionary Genetics Analysis version 6.0. Mol. Biol. Evol. 30: 2725-9. DOI: http:// dx.doi.org/10.1093/molbev/mst197.

Tentcheva, D., Gauthier, L., Bagny, L., Fievet, J., Dainat, B., Cousserans, F., Colin, M.E. \& Bergoin, M. 2006. Comparative analysis of deformed wing virus (DWV) RNA in Apis mellifera and Varroa destructor. Apidologie 37: 41-50. DOl: http://dx.doi.org/10.1051/apido:2005057.

Tentcheva, D., Gauthier, L., Zappulla, N., Dainat, B., Colin, M.E. \& Bergoin, M. 2004. Prevalence and Seasonal Variations of Six Bee Viruses in Apis mellifera and Varroa destructor Mite Populations in France. Appl Environ Microbiol 70: 7185-7191. DOI http://dx.doi. org/10.1128/AEM.70.12.7185-7191. 